\title{
The Effect Of Geg, Csr And Profitability On Firm Value At Sri Kehati Index Listed On Bei 2015 - 2017
}

\author{
$1^{\text {st }}$ Minanari $^{1}, 2^{\text {nd }}$ Misbah Abdir Rohman ${ }^{2}$ \\ \{minanari@mercubuana.ac.id ${ }^{1}$, misbahabdirrohman@gmail.com² ${ }^{2}$ \\ Economic and Business Faculty, Mercu Buana University, Jakarta, Indonesia ${ }^{12}$
}

\begin{abstract}
This study aims to determine the effect of Managerial Ownership, Institutional Ownership, CSR Disclosure and Profitability on Firm Value. Study on SRI KEHATI index listed on the Indonesia Stock Exchange in 2015-2017. This type of research uses secondary data sources in the form of annual financial reports and sustainability report on SRI KEHATI index listed on the Indonesia Stock Exchange for the period 2015-2017. The population in this study is a company on SRI KEHATI index listed on the Indonesia Stock Exchange for the 2015-2017 period. A sample of 20 companies was obtained from 25 populations in this study. The analysis technique used in this study is multiple linear regression analysis with Eviews 9 program. The results of this study indicate that Managerial Ownership has a significant negative effect on the Firm Value while Institutional Ownership and CSR Disclosure do not significantly affect the Firm Value, and Profitability has a significant effect on the Firm Value.
\end{abstract}

Keywords: Managerial Ownership, Institutional Ownership, CSR Disclosure, Profitability, Firm Value.

\section{Introduction}

Increasing the value of a firm is usually marked by an increase in stock prices in the market. If the value of the firm continues to increase, it is certain that share prices and shareholder prosperity are also increasing (1)(2)(3). The SRI KEHATI Index, SRI is short for Sustainable Responsible Investment, KEHATI is Indonesian Biodiversity Foundation. Companies in this index have very good performance in encouraging sustainable business, as well as having an awareness of the environment and implementing good corporate governance.

\section{Literatur Reviews}

Jensen and Meckling (1976)(4) explain the existence of conflicts of interest in agency relationships. This conflict of interest is due to the different objectives of the manager and principal. Managers are agents with the obligation to maximize the welfare of the owner of the company (principal). Managers also have an interest in maximizing their own welfare. Coupled with the separation between ownership and control, causes managers to take action to 
increase their own welfare without thinking about the interests of shareholders. Agents manage the company, agents have more information about the capacity of the company, the work environment and the company as a whole.

Previous studies related to the SRI KEHATI index, namely the Citraningrum et al. (2014) (5) that CSR affects the EPS of the company. CSR is considered to affect earnings per share. Investors consider CSR carried out by the company. as a mandatory for the company. CSR has an effect on Closing Price. Price Closing is now one of the considerations of external companies to assess company performance (firm value).

According to Shinta et al. (2015) the implementation of good corporate governance do not influence both stock return and volatility, but Rachman et al. (2015) prove that Good Corporate Governance (GCG) has a significant effect on Financial Performance and Good Corporate Governance (GCG) has no significant effect on Firm Value(6)(7)(8)(9)(10)(11)(12)(13).

\section{Research Model, Hypotheses, and Methodology}

The design of this study is causal (causal), which is a relationship that affects two or more variables.

Based on the background of the problem and the formulation of the problem, the hypothesis can be formulated as follows:

1. Effect of Managerial Ownership on Firm Values

H1: Managerial Ownership influences Firm Value

2. Effect of Institutional Ownership on Firm Values

H2: Institutional Ownership influences Firm Value

3. Effect of CSR Disclosure on Firm Values

H3: CSR Disclosure influences Firm Value

4. Effect of Profitability on Firm Value

H4: Profitability influences Firm Value

\subsection{Defendent Variables}

In this study, company value was measured using Tobin's $\mathrm{Q}$ with the following formula:

$$
\mathbf{q}=(\mathbf{M V E}+\mathrm{D}) / \mathrm{TA}
$$

Where :

$$
\begin{array}{ll}
\mathrm{q} & =\text { Tobin's Q } \\
\text { MVS } & =\text { Market value of all outstanding shares } \\
\text { D } & =\text { Debt } \\
\text { TA } & =\text { Firm's assets }
\end{array}
$$

\subsection{Independent Variables}


1. GCG as measured by managerial ownership shares

This variable is measured by the percentage of total shares of all executive directors compared to total shares (El-Chaarani, 2014) (14). From this research, the formula:

KM = Management owned shares / Total outstanding shares

2. GCG is measured by institutional ownership shares

Institutional ownership is expressed as a percentage (\%) by comparing the number of shares held by institutional investors divided by the total number of shares outstanding $(15)(16)(17)(18)(19)(20)(21)(22)(23)$. From this research, the formula:

\section{KI = Institutional shares / Total outstanding shares}

3. Disclosure CSR

CSRI calculations referring to GRI G4 are done in a dummy manner, ie each CSRI item is given a value of 1 if expressed, a value of 0 if not disclosed, the score of each item is added up. The CSRI calculation formula is as follows:

$$
\text { CSRij }=\Sigma X i j / ~ N j
$$

Where :

CSRij $\quad=$ Corporate Social Responsibility Corporate Disclosure Index j

$\mathrm{Nj} \quad=$ Number of items expected

Exij $\quad=$ Number of items disclosed by the company

4. Profitability proxied by Return On Equity (ROE)

Profitability is measured by the ratio of Return on Equity (ROE) (19)(24)(25)(26)(27)(28). ROE formula, namely:

ROE = Company's Net Income / Common Shareholder'sequity

Table 1. Sampling Technique

\begin{tabular}{|c|l|c|}
\hline No & \multicolumn{1}{|c|}{ Kriteria } & Jumlah \\
\hline 1 & $\begin{array}{l}\text { Company registered with the SRI KEHATI index on the Indonesia Stock } \\
\text { Exchange (IDX) during the period 2015-2017 }\end{array}$ & 25 \\
\hline 2 & $\begin{array}{l}\text { Companies on the Indonesia Stock Exchange (IDX) during the 2015-2017 } \\
\text { period are not continuously listed on the SRI KEHATI index. }\end{array}$ & $(5)$ \\
\hline \multicolumn{2}{|c|}{ Samples studied } & 20 \\
\hline Amount of data in research 20 x 3 years & 60 \\
\hline
\end{tabular}




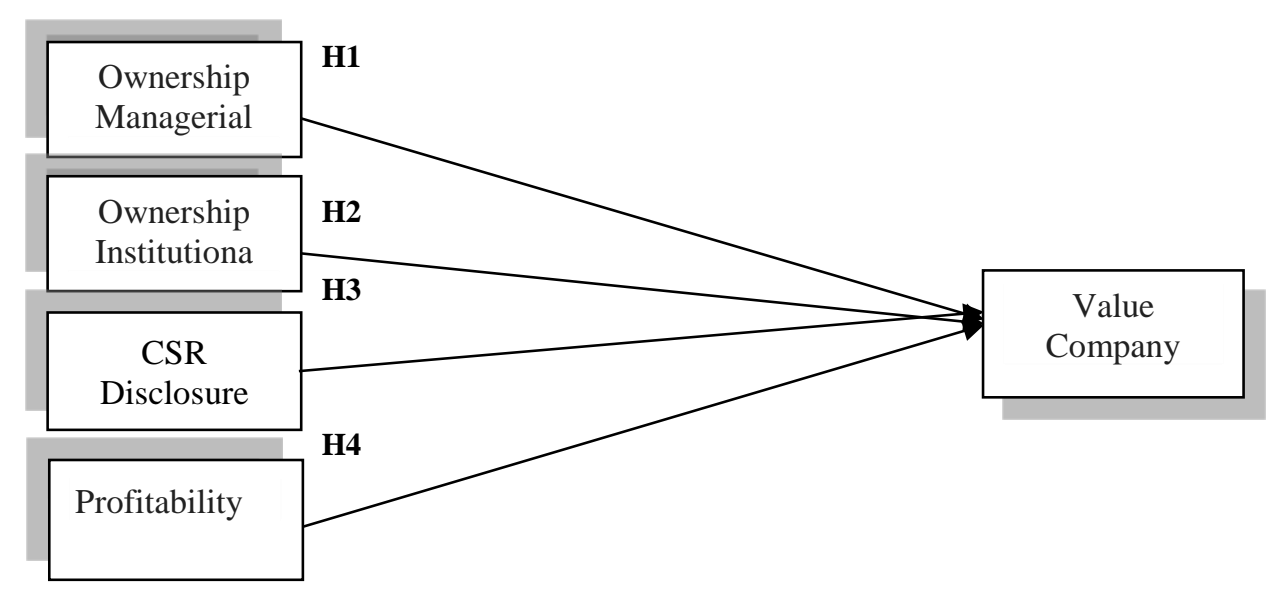

\subsection{Thinking Framework}

The research objective was to examine the effect of managerial ownership, institutional ownership, corporate social responbility and financial performance which is an independent variable (free) and the dependent variable (bound), namely the firm value. The analytical method used in this study is the Test of Descriptive Statistics, Classical Assumption Test and concludes with a Hypothesis Test.

The method in this study is a quantitative method, meaning that the variables in the study are realized with certain values. The analysis in this study uses panel data which is a combination of time-series data and cross-sectional data(29).

There are two types of data panels, namely panel balance data and unbalance panel data, panel balance data is a situation in which cross-sectional units have the same number of time series observations. Whereas unbalance panel data is a condition in which cross-sectional units have an unequal number of time series observations. In this study using panel balanced data with the Generalize Least Square (GLS) approach and data processing in this study using the E-Views 9 program.

\section{Result and Discussion}

\subsection{Descriptive Statistic Analysis}

Table 2. Descriptive Statistics Test Results

\begin{tabular}{lccccc}
\hline & Tobin's Q & KM & KI & CSRI & ROE \\
\hline Mean & 2.477801 & 0.003231 & 0.609214 & 0.331500 & 0.203287 \\
Median & 1.296355 & $6.50 \mathrm{E}-05$ & 0.473340 & 0.295000 & 0.137650 \\
Maximum & 23.28626 & 0.041370 & 0.990280 & 0.730000 & 1.358000 \\
\hline
\end{tabular}




\begin{tabular}{lccccc}
\hline Minimum & 0.826510 & 0.000000 & 0.180060 & 0.090000 & 0.020000 \\
Std. Dev. & 4.196319 & 0.009061 & 0.293215 & 0.151275 & 0.264895 \\
Observatio & 60 & 60 & 60 & 60 & 60 \\
ns & & Source: Output &
\end{tabular}

Source: Output results of Eviews 9 (processed)

1. Tobin's Q's average value is 2.465946 , meaning that the company including the SRIKEHATI index has a market value of around 2.5 times greater than its book value (overvalued). The standard deviation of the value 4.196319 is above the average value, indicating that the calculated average in the observed data has not been able to represent the actual picture of Tobin's Q, so it is not good to deduce from Tobin's Q average because there are sufficient deviations in value large on sample data observed. The minimum value of Tobin's Q is 0.826510 , which is from Timah (Persero) Tbk in 2015 and the maximum value at Unilever Indonesia Tbk in 2017 which has a value of 23.28626 .

2. The average value of Managerial Ownership Shares (KM) is 0.003231, meaning managerial ownership is only $0.003 \%$. This signifies management participation that is less active in influencing company value. The standard deviation of 0.009061 is greater than the calculated average, indicating that the calculated average in the observed data has not been able to represent the actual KM picture. The minimum value of Managerial Ownership in PP London Sumatran Indonesia Tbk from 2015 to 2017 is 0\% with the maximum value of Managerial Ownership in Astra Argo Lestari Tbk in the same period with a value of $4.14 \%$.

3. The average value of the Institutional Ownership Shares (KI) is high at 0.609214 . This indicates that control of management for efficiency is very active and good. The standard deviation of 0.293215 is lower than the calculated average, indicating that the deviation of data from the sample in the KI variable is relatively small so that the calculated average value can already describe the real condition of the KI variable. The minimum value on the KI variable in the observed period, is $18 \%$ owned by Pembangunan Jaya Ancol Tbk in the period 2015 to 2017 and the maximum value of the KI variable is $99 \%$ owned by Unilever Indonesia Tbk in the same period.

4. CSRI average value of $30.15 \%$ with a standard deviation of 0.151275 smaller than the calculated average, so that the calculated average is considered to have been able to describe the actual state of CSRI variables and this illustrates how much the company's participation in social responsibility.The minimum number of CSRI numbers is Adhi Karya (Persero) Tbk at $9 \%$ in the period 2015 to 2017 and the maximum value is equal to Bank Mandiri in 2016 of $73 \%$.

5. Profitability average value of $20.34 \%$ affects the level of increase in stock prices and the value of the company. The calculated average value has not been able to describe the actual ROE variable state, this is seen from the standard deviation value of 0.264895 which is higher than the calculated average value. The minimum ROE variable value, namely in Timah (Persero) Tbk in 2015 amounted to $2 \%$ and the maximum value is owned by Unilever Indonesia Tbk in 2016 amounting to $135.80 \%$. 


\subsection{Classical Assumption Test}

Table 3. Results Of Egls Classical Assumptions

\begin{tabular}{lll}
\hline Test & Probability & Explanation \\
\hline \multirow{2}{*}{ Normalityy } & $\mathrm{JB}=1.472784<$ Table $\mathrm{x}^{2}$ & \multirow{2}{*}{ Normal } \\
& Table $\mathrm{x}^{2}=73.31149$ & \\
& $\mathrm{KM}=0.3604$ & \\
Heterocedasticity & $\mathrm{KI}=0.1217$ & Heterocedasticity free \\
& $\mathrm{CSRI}=0.1357$ & \\
& $\mathrm{ROE}=0.7310$ & \\
& $\alpha=0.05$ & Autocorrelation free \\
Autocorrelation & $\mathrm{dw}=2.398780$ & \\
\multirow{3}{*}{ Multicollinearity } & $\mathrm{d}=1.4443, \mathrm{du}=1.7274$ & Multicollinearity free \\
& Correlation between independent & \\
& variables $<0.90$ &
\end{tabular}

Based on the results of the classic assumption test in table 4.3 above, after weighting on the Fixed Effect (FEM) / Least Squares (PLS) model or called the EGLS Panel model (Crosssection) it is known based on JB Test, JB value after weighting is 1.472784 smaller compared to table $\mathrm{x}^{2}$ which is 73.31149 , thus the research data is normally distributed. Heteroscedasticity test shows the value of the probability value of each independent variable above $\alpha=0.05$, it can be concluded that the EGLS Panel model has been free from heteroscedasticity. The autocorrelation test in the table shows a dw value of 2.398780, the value is greater than the value $\mathrm{du}=1.7274$, and smaller than $4-\mathrm{dL}=4-1.4443$ is 2.5557 so that it can be seen that the model is free from autocorrelation. Multicollinearity test can be seen in the attachment that all independent variables obtain values below 0.90 which means that the variable data model of this study has been free from multicollinearity.

\subsection{Test the Hypothesis}

Table 4. Results Of Hypothesis Test

\begin{tabular}{lllll}
\hline \multicolumn{5}{c}{ Uji t } \\
\hline Variablele & Probability & $t$-statistic & Coefficient & Explanation \\
\hline KM & 0.0031 & -3.177015 & -0.101876 & Significant \\
KI & 0.2691 & 1.122542 & 0.278251 & Not significant \\
CSRI & 0.2292 & 1.223289 & 0.384465 & Not significant \\
ROE & 0.0000 & 4.789188 & 0.690080 & Significant \\
\hline \multicolumn{5}{c}{ Uji f } \\
\hline Variablele & Probability & f-statistic & Explanation \\
\hline KM, KI, CSRI, ROE & 0.0000 & 224.910 & Significant \\
Adjusted R-squared & \multicolumn{5}{c}{ Expalanation } \\
0.988673 & \multicolumn{5}{c}{ Perdurable } \\
\hline
\end{tabular}

Source: Results Eviews 9 (data processed) 
Based on the test results, the panel data regression equation can be arranged as follows:

Tobin's q $=2.966990-0.101876 * \mathrm{KM}+0.278251 * \mathrm{KI}+0.384465 * \mathrm{CSRI}+0.690080$ $* \mathrm{ROE}+\mathrm{e} . \mathrm{it}$

The results of hypothesis testing to determine the effect of independent variables (KM,

KI, CSRI and ROE) on the dependent variable Tobin's Q are as follows:

1. The value of the $t$ test is used to see the influence of independent variables (KM, KI, CSRI and ROE) on the dependent variable Tobin's Q partially on the companies included in the SRI-KEHATI index. From the results of panel data regression it is known that KM and ROE have a significant effect on the dependent variable Tobin's Q while the influential KI and CSRI.

2. Test Value $\mathrm{f}$ is known to be a significance value $<\alpha=5 \%$ with a probability of 0.000000 below 0.05. Then, $\mathrm{H} 0$ is rejected and $\mathrm{H} 1$ is accepted which means that the independent variables (KM, KI, CSRI and ROE) simultaneously or together (simultaneous) have a significant effect on the dependent variable Tobin's Q.

3. Adjusted R-squared value in the SRI-KEHATI index of 0.988673 shows that variations in Tobin's Q changes are able to be explained simultaneously by the variables KM, KI, CSRI and ROE of $98.88 \%$, while the remaining $1.12 \%$ is explained by other factors which is not included in the model.

The results of the regression equation, the coefficient $\mathrm{C}$ is 2.966990 , if it is assumed that the KI, CSRI and ROE variables are 0, then the company value proxied by Tobin's Q in the SRI-KEHATI index increases by 2,966,990 times. Whereas if the KM variable is 0 , then the company value proxied by Tobin's Q in the SRI-KEHATI index has decreased by $2,966,990$ times. The individual effects of variables based on regression calculations are as follows(30):

1. Effect of Stock Managerial Ownership (KM) on Firm Values (Tobin's Q)

From the results of regression calculations, managerial ownership shares (KM) have a significant negative effect on firm value (Tobin's Q). Thus, the first hypothesis which states that managerial ownership (KM) shares influence the firm's value (Tobin's Q) is acceptable. The smaller the percentage of managerial ownership shares, the higher the firm value. A conflict of interest occurs due to differences in the objectives of each party. Managers as agents have an obligation to maximize the welfare of the owners of the company (principal). On the other hand, managers also have an interest in maximizing their own welfare. The results of this study are not in accordance with previous studies conducted (31). The results of the study state that an increase in the number of managerial ownership can reduce agency conflicts arising from agency relationships.

2. The Influence of Institutional Ownership Shares (KI) on Firm Values (Tobin's Q) From the results of regression calculations, institutional ownership shares (KI) have no significant effect on firm value (Tobin's Q). Thus, the second hypothesis which states that institutional ownership variables (KI) have an effect on firm value (Tobin's Q) is acceptable. This is because when potential investors will invest in shares, prospective investors do not see who the institutional investors are because of course, in the SRI KEHATI index company, the shares are owned by large institutions, both of which are owned by BUMN. Because the average institutional ownership index of the SRI KEHATI index is $61 \%$ and describes the actual situation, this can be seen from the value of the standard deviation which is lower than the average share of institutional ownership. Data deviations from the sample are relatively small so that the calculated average value can already describe the actual situation. The results of this study are in accordance with the results of research conducted [15]. 
3. Effect of CSR disclosure (CSRI) on Firm Values (Tobin's Q)

From the results of regression calculations, CSRI has no significant effect on firm value (Tobin's Q). Thus, the third hypothesis which states that CSRI has an effect on firm value (Tobin's Q) is acceptable. Companies that are included in the SRI KEHATI index list have very good CSR Disclosures with the GRI guidelines so that this affects the insignificant value of companies in this study. Because the average SRI KEHATI CSR disclosure index is 33\% and describes the actual situation, this can be seen from the standard deviation value which is lower than the average CSR disclosure. Data deviations from the sample are relatively small so that the calculated average value can already describe the actual situation. The results of this study are still in accordance with the results of research conducted by Umro and Fidiana (2016) with the result that CSR has a significant effect on firm value. This shows that the company has done a good Corporate Social Responsibility (CSR)(32)(33)(34)(35).

4. Effect of Profitability (ROE) on Firm Values (Tobin's Q)

From the results of regression calculations, ROE has a significant effect on firm value (Tobin's Q). Thus, the fourth hypothesis which states that ROE has an effect on firm value (Tobin's $\mathrm{Q}$ ) is acceptable. The high ROE value becomes a positive signal for investors in investing to get a certain return, the stock price will increase. The stock price increases reflecting the firm value in good condition. The higher the level of profitability of the company the better the value of the company. The results of this study are in line with the results of research conducted by Kurnia (2015), profitability ratios measure the ability of companies to produce financial at a certain level of sales, assets, and share capital.

\section{Conclusion}

Based on the results of the research that has been done, the conclusions of this study are as follows:

1. Managerial ownership share have a significant negative effect on firm value. This means that the higher the managerial ownership shares, the increase in the number of managerial ownership is not able to reduce agency conflicts arising from agency relationships and because the ownership of shares obtained by managers is very small or even nonexistent, so that the ownership of the company and manager's motivation to improve performance and company value is less owned by the managers. On the other hand, managers also have an interest in maximizing their own welfare.

2. Institutional ownership shares have no significant effect on firm value. When potential investors will invest in shares, prospective investors do not see who the institutional investors are because of course the SRI KEHATI index company is owned by a large, good institution and there are several shares owned by BUMN. Because the average institutional ownership index of the SRI KEHATI index is $61 \%$ and describes the actual situation, this can be seen from the value of the standard deviation which is lower than the average share of institutional ownership. Data deviations from the sample are relatively small so that the calculated average value can already describe the actual situation.

3. CSR disclosure has no significant effect on firm value. This is due to the presence of CSR disclosures, investors will respond positively to many investors who invest in these companies which will cause an increase in the value of the company. Based on the 
Exchange and Sustainable Investment data, the SRI KEHATI index is listed as the first index of green investment in ASEAN and second in Asia(36).

4. Profitability has a significant effect on firm value. The higher the company's profit, the higher the value of the company. High profitability causes stock prices to increase. Increased stock prices reflect that the firm value is in good condition.

\section{References}

1. Mariatun, Sriwidodo U, Wibowo E. Kinerja Keuangan, Corporate Social Responsibility, Nilai Perusahaan, Dan Good Corporate Governance. J Ekon dan Kewirausahaan. 2017;Vol.17(April 2017):pp: 119-127.

2. Pan, X., Sha, J., Zhang, H., \& Ke W. Relationship Between Corporate Social Responsibility And Financial Performance In The Mineral Industry: Evidence From Chinese Mineral Firms. Sustainability 2014. 2017;4077-101.

3. Putri AK, Sudarma M, Purnomosidhi B. Pengaruh Corporate Social Responsibility terhadap Nilai Perusahaan dengan Ukuran Perusahaan dan Jumlah Dewan Komisaris sebagai Variabel Pemoderasi (Studi pada Perusahaan Manufaktur yang terdaftar Bursa Efek Indonesia). J Apl Manaj. 2016;14(2).

4. Jensen MC, Meckling WH. Theory of The Firm: Managerial Behavior, Agency Costs and Ownership Structure. J financ econ [Internet]. 1976 [cited 2019 Jun 26];3:305-60. Available from: http://117.211.153.211:8001/jspui/bitstream/123456789/335/1/1-s2.0-

0304405X7690026X-main.pdf

5. Citraningrum D. PENGARUH CORPORATE SOCIAL RESPONSIBILITY (CSR) TERHADAP FINANCIAL PERFORMANCE DAN FIRM VALUE (Studi pada PeruusahaanPerusahaan yang Terdaftar Pada Indeks SRI KEHATI Periode 2010-2012). J Adm Bisnis. 2014;14(1).

6. SSanchia, 1. I., \& Zen TS. Impact Of Good Corporate Governance In Corporate Performance. International Journal Of Management And Applied Science. 2015;102-6.

7. Sarah RM. The benefits of good corporate governance to small and medium enterprises (SMEs) in South Africa: A view on top 20 and bottom 20 JSE listed companies. Probl Perspect Manag. 2017;15(4):271-9.

8. Sari, D. A., \& Riduwan A. Kinerja Keuangan, Corporate Social Responsibility, Good Corporate Governance Dan Nilai Perusahaan. Jurnal Ilmu \& Riset Akuntansi. 2015;4 no.5:1-18.

9. Susanto, C. M., \& Ardini L. Pengaruh Good Corporate Governance, Corporate Social Responsibility, Dan Profitabilitas Terhadap Nilai Perusahaan. Jurnal Ilmu Dan Riset Akuntansi. 2016;5 no. 7:1-17.

10. Syafitri T et al. Pengaruh Good Corporate Governance Terhadap Nilai Perusahaan ( Studi pada perusahaan industri sub sektor logam dan Sejenisnya yang terdaftar di bei periode 2012-2016). J Adm Bisnis. 2018;56(1):118-26.

11. Tarigan J, Semuel H. Pengungkapan Sustainability Report dan Kinerja Keuangan. J Akunt dan Keuang. 2015;16(2):88-101.

12. Tertius MA, Christiawan YJ. Pengaruh Good Corporate Governance terhadap Kinerja Perusahaan pada Sektor Keuangan. Bus Account Rev [Internet]. 2014;3(1):223-32. Available from: publication.petra.ac.id/index.php/akuntansi-bisnis/article/view/2763/2474

13. Shinta Melzatia, Sri Rahayu and FI. Analisis Pengaruh Implementasi Good Corporate Governance Terhadap Return dan Volatilitas Saham. Jurnal Profita Vol 7, No 1. Universitas Mercu Buana. 2015;7.

14. Ocampo LE, Alarcón MA, Fong C. Determinants of the Internationalization of the Firm: the Accelerated Model Vs the Sequential Model. Int J Bus Financ Res [Internet]. 2014;8(5):81-93. 
Available from: http://www.theibfr.com/ARCHIVE/IJBFR-V8N5-2014.pdf

15. Bawafi, M. H., \& Prasetyo A. Pengaruh Pengungkapan Corporate Social Responsibility Terhadap Nilai Perusahaan Dengan Profitabilitas Sebagai Variabel Pemoderasi. Jurnal Reviu Akuntansi Dan Keuangan Vol.5 No. 1, 721-729. 2015;

16. Gherghina ŞC. Corporate governance ratings and firm value: Empirical evidence from the Bucharest stock exchange. Int J Econ Financ Issues. 2015;5(1):97-100.

17. Gherghina ŞC, Vintilă G. Exploring the impact of corporate social responsibility policies on firm value: The case of listed companies in Romania. Econ Sociol. 2016;9(1):23-42.

18. Ghozali I. Aplikasi Analisis Multivariate Dengan Program Ibm. Spss 21, Update Pls Regresi. Semarang: Badan Penerbit Universitas Diponegoro. "Aplikasi analisis multivariate dengan Prodram Spss. 2013.

19. Han J-J, Kim HJ, Yu J. Empirical study on relationship between corporate social responsibility and financial performance in Korea. Asian J Sustain Soc Responsib. 2016;1(1):61-76.

20. Hasnawati S, Sawir A. Keputusan Keuangan, Ukuran Perusahaan, Struktur Kepemilikan Dan Nilai Perusahaan Publik Di Indonesia. J Manaj dan Kewirausahaan (Journal Manag Entrep. 2015;17(1):65-75.

21. Margaretha F, Witedjo CG. Csr, Nilai Perusahaan Dan Kinerja Keuangan Perusahaan Pada Industri Pertambangan Dan Manufaktur Di Indonesia. Media Ris Akuntansi, Audit dan Inf. 2017;14(1):89.

22. Prastuti N, Budiasih I. Pengaruh Good Corporate Governance Pada Nilai Perusahaan Dengan Moderasi Corporate Social Responsibility. E-Jurnal Akunt. 2015;13(1):114-29.

23. Santoso A. Pengaruh Good Corporate Governance Terhadap Nilai Perusahaan dengan Kinerja Keuangan sebagai Variabel Intervening. In: Prosiding Seminar Nasional dan Call For Paper Ekonomi dan Bisnis. Jember; 2017. p. 67-77.

24. Ratih S, Setyarini Y. Pengaruh Good Corporate Governance (Gcg) Dan Corporate Social Responsibility (Csr) Terhadap Nilai Perusahaan Dengan Kinerja Keuangan Sebagai Variable Intervening Pada Perusahaan Pertambangan Yang Go Public Di Bei. AKRUAL J Akunt. 2014;5(2):115.

25. Wijaya M. Pengaruh Penerapan Good Corporate Governance Dan Corporate Social Responsibility Terhadap Nilai Perusahaan (Studi Empiris Pada Perusahaan Bumn Yang Terdaftar Di Bursa Efek Indonesia 2012-2014). Jom Fekon. 2017;4 no.1:1081-95.

26. Windasari, O., \& Riharjo IB. Pengaruh Good Corporate Governance, Profitabilitas Dan Corporate Social Responsibility Terhadap Nilai Perusahaan. Jurnal Ilmu Dan Riset Akuntansi. 2017;6 no. 10:1-20.

27. Yudharma et al AS. Pengaruh Biaya Corporate Social Responsibility Terhadap Kinerja Keuangan dan Nilai Perusahaan. DeReMa J Manaj Vol. 2016;11(2):171-90.

28. Zarlia J, Salim H. Analisis Pengaruh Corporate Social Responsibility Dan Profitabilitas Terhadap Nilai Perusahaan: Studi Empiris Pada Perusahaan Manufaktur Yang Terdaftar Di Bursa Efek Indonesia Tahun 2013. J Manaj. 2014;11(2):136-54.

29. Wati N. Metodologi Penelitian Terapan. Jakarta: Cv. Mujahid Press. 2018;

30. Moeljadi. Factors Affecting Firm Value: Theoretical Study On Public Manufacturing Firms In Indonesia. South East Asia Journal Of Contemporary Business, Economics And Law, Vol. 5, Issue 2, 6-15. 2014;

31. Setiawan E, Christiawan YJ. Pengaruh Penerapan Corporate Governance Terhadap Nilai Perusahaan dengan Ukuran Perusahaan dan Leverage sebagai Variabel Kontrol. Bus Account Rev. 2017;5(2):373-84.

32. Syardiana G, Rodoni A, Putri ZE. Pengaruh Investment Opportunity Set, Struktur Modal, Pertumbuhan Perusahaan, Dan Return on Asset Terhadap Nilai Perusahaan. Akuntabilitas. 2016;8(1):39-46.

33. Umro, M. \& F. Pengaruh Corporate Social Responsibility Dan Profitabilitas Terhadap Nilai Perusahaan. Jurnal Ilmu Dan Riset Akuntansi. 2016;5 no. 1:1-15.

34. Wang, D. H.-M., Chen, P.-H., Yu, T. H.-K., \& Hsiao C-Y. The Effects Of Corporate Social Responsibility On Brand Equity And Firm Performance. Journal Of Business Research. 2015;1- 
5 .

35. Wibowo, et al. Pengaruh csr disclosure dan gcg terhadap nilai perusahaan dengan kinerja keuangan sebagai variabel intervening di perusahaan manufaktur yang terdaftar di bursa efek indonesia (2012-2014). Pengaruh Csr Discl Dan Gcg Terhadap Nilai Perusah Dengan Kinerja Keuang Sebagai Var Interv Di Perusah Manufaktur Yang Terdaftar Di Bursa Efek Indones. 2016;926-35.

36. Shaun Cochran, C., Allen, J., \& Yonts C. Cg Watch 2016, Ecosystems Matter : Asia's Path To Better Home-Grown Governance. Asia: Acga. 2016; 